\title{
Health status, lifestyle habits, and perceived social support in long-term cancer survivors: a cross-sectional study
}

Beatriz León-Salas 1,23, Edurne Zabaleta-del-Olmo 24,5,6,7, Joan Llobera 2,8,9 Bonaventura Bolíbar-Ribas 24,7 , Tomás López-Jiménez ${ }^{2,4,7}$, Marc Casajuana-Closas ${ }^{2,4,7}$ and Magdalena Esteva ${ }^{2,8, *^{*}}$ (])

\begin{abstract}
Objective: To compare the presence of comorbidities and self-perceived health and social support between longterm cancer survivors and people without a history of cancer from a clinical trial examining the effects of a multiple risk behavior intervention.

Results: Of the 4259 people studied, 190 (4.46\%) were cancer survivors. They had a mean \pm SD age of $62.8 \pm 7$ years vs. $58.7 \pm 8$ years $(P<0.01)$ for non-cancer people and were more likely to be on long-term sick leave $(11.9 \mathrm{vs.} 3.5 \%$, $\mathrm{P}<0.001)$. No differences were observed for smoking, adherence to the Mediterranean diet, physical activity, obesity, or social support. Cancer survivors were more likely to have worse self-perceived health (OR 1.82; 95\% Cl 1.02-2.75), more comorbidities (OR 1.68; 95\% Cl 1.18-2.39), COPD (OR 2.17; 95\% Cl 1.25-3.78), and depression (OR 1.65; 95\% Cl 1.06-2.57). Older age and worse self-perceived health were independent predictors of survivorship in the adjusted analysis.
\end{abstract}

Keywords: Primary care, Cancer, Survivorship, Lifestyle, Comorbidity, Quality of life, Health promotion

\section{Introduction}

More and more people are surviving cancer thanks to advances in early detection and diagnostic techniques and treatment. Survival rates are increasing worldwide, even for the most aggressive forms of cancer [1]. In Spain, over $50 \%$ of adults are still alive 5 years after diagnosis [2] and the estimated number of prevalent cases at 5 years exceeds 500,000 [3]. These trends call for greater attention to be paid to long-term cancer survivorship.

As explained by Grunfel and Earle [3], "the period after completing primary and adjuvant cancer treatment until recurrence or death is now recognized as a unique phase in the cancer control continuum. Survivorship is a time

\footnotetext{
*Correspondence: mesteva@ibsalut.caib.es

${ }^{8}$ Unit of Research Majorca Department of Primary Care, Balearic Health

Service, Escola Graduada 3, 07002 Palma, Majorca, Spain

Full list of author information is available at the end of the article
}

of transition: Issues related to diagnosis and treatment diminishes in importance, and concerns related to longterm follow-up care, management of late effects, rehabilitation, and health promotion dominate."

Cancer survivors may develop other conditions as a result of their cancer treatment. Some of these are transient, but others can become chronic and significantly affect quality of life [4]. Cancer survivors may also be at increased risk of a second cancer if the risk factors associated with the original cancer persist. There is increasing evidence that interventions aimed at promoting healthy eating, regular exercise, and maintenance of a healthy weight can offset some of the adverse effects of cancer and cancer treatment [5-10]. Alongside smoking cessation, these behaviors reduce not only the risk of cancer recurrence but also the risk of other health conditions, such as cardiovascular disease, diabetes, and other cancers [11-13]. Cancer also has social impacts in the form

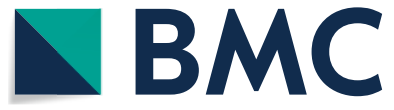

(c) The Author(s) 2020. This article is licensed under a Creative Commons Attribution 4.0 International License, which permits use, sharing, adaptation, distribution and reproduction in any medium or format, as long as you give appropriate credit to the original author(s) and the source, provide a link to the Creative Commons licence, and indicate if changes were made. The images or other third party material in this article are included in the article's Creative Commons licence, unless indicated otherwise in a credit line to the material. If material is not included in the article's Creative Commons licence and your intended use is not permitted by statutory regulation or exceeds the permitted use, you will need to obtain permission directly from the copyright holder. To view a copy of this licence, visit http://creativecommons.org/licenses/by/4.0/. The Creative Commons Public Domain Dedication waiver (http://creativecommons.org/publicdomain/zero/1.0/) applies to the data made available in this article, unless otherwise stated in a credit line to the data. 
of job loss or change and difficulties with social and personal relationships [14]. Although the health and quality of life of cancer survivors are important public health issues, knowledge in this area is still lacking, particularly in Spain [15].

The aim of this study was to compare the presence of comorbid conditions and self-perceptions of health and social support between long-term cancer survivors and people without a history of cancer from a clinical trial examining the effects of a multiple risk behavior intervention.

\section{Main text Methods}

We performed a cross-sectional multicenter study nested within phases II and III of the ERIA trial, a parallel cluster randomized clinical trial designed to analyze the effects of a complex individual and group multiple risk intervention on the uptake of healthy behaviors (smoking cessation, adherence to the Mediterranean diet, and sufficient levels of physical activity). The trial was conducted in accordance with the Medical Research Council guidance on complex interventions [16]. The definitive (phase III) trial was launched after the exploratory phase II trial. It was conducted between 2014-2015 and 2016-2018 by the Primary Care Prevention and Health Promotion Network (RedIAPP) in 38 primary care centers in 11 Spanish provinces. The trial protocol has been published [17].

The participants were recruited by their general practitioners (GPs). Inclusion criteria were: (1) be aged between 45 and 75 years, (2) be registered with a GP participating in the study and have had arranged an appointment with their GP or nurse, and (3) have two of the following risk behaviors: smoking, low adherence to the Mediterranean diet, and insufficient physical activity. Cardiovascular risk and depression had been used as inclusion criteria in the exploratory phase II trial, but were eliminated in the phase III trial due to feasibility issues. Exclusion criteria were cognitive impairment, dependency in activities of daily living, severe mental disease, long-term home care and active or palliative cancer treatment. The flow of participants through the study is shown in Additional file 1: Figure S1.

Based on the assumption that $50 \%$ of cancer survivors and $40 \%$ of non-cancer patients would rate their health as fair or poor, we estimated that the study would be powered at $78 \%$ with a confidence level of $95 \%$.

For this sub-study, the variables analyzed were those measured at the baseline interview (i.e., before any intervention). The dependent variable was presence or absence of a cancer diagnosis. The subjects were thus divided into cancer survivors (patients diagnosed with cancer who met the criteria for survivorship) and patients without a history of cancer). Cancer survivorship was defined as the period from completion of primary or adjuvant cancer treatment to recurrence, death, or cure. ClinicalTrials.gov, NCT03136211.

Other baseline variables were (1) sociodemographic variables, namely age, sex, level of education, civil status, and employment status, classified as working/not working (homemaker, retiree, student) unemployed and long-term sick leave; (2) perceived social support measured using the Duke-UNC questionnaire [18, 19], $(<32$ points indicating low support); (3) self-perceived health status; (4) comorbidity measured using the non-cancer Charlson Comorbidity Index (CCI) [20]; (5) lifestyle habits, namely smoking (yes/no); adherence to the Mediterranean diet measured using the 14-item PREDIMED scale [21], where $0-8$ points indicates low adherence) [5]; and physical activity, assessed using the Brief Physical Activity Assessment tool for primary care [22, 23], where patients are classified as sufficiently active if they perform three or more 20 -min vigorous activity sessions, five or more 30-min moderate activity sessions, or five or more sessions of any combination of moderate and vigorous sessions. If they do not meet these criteria, they are classified as insufficiently active.

We performed a bivariate analysis to investigate associations between independent variables and being in the cancer survivor group or the non-cancer group; the $X^{2}$ test was used for categorical variables and the $t$ test for continuous variables. Statistical significance was established as $\mathrm{P}<0.05$. Odds ratios with $95 \%$ confidence intervals (CIs) were calculated to assess strength of association. Finally, we performed multiple logistic regression analysis of variables with a $P$ value $<0.20$ in the bivariate analysis using backward elimination. Whenever a variable was eliminated from the model, changes to the B coefficients were checked to assess confounding. Statistical analyses were performed in SPSS, version 23. The study was approved by the ethics committees at each of the participating centers.

\section{Results}

In total, 4259 people were included in the study: 190 cancer survivors (4.46\%; 95\% CI 3.82-5.09) and 4069 noncancer patients. The median time since diagnosis was 6.5 years (interquartile range, $3-10$ years).

The sociodemographic variables are summarized in Table 1. Patients who had survived cancer were on average older than those without a history of cancer, but no significant differences were observed for sex or civil status. In the cancer survival group, there were higher proportions of patients not working, patients with long-term sick leave, and patients with primary education or no schooling. 
Table 1 Sociodemographic characteristics of study participants

\begin{tabular}{lcc}
\hline Sociodemographic variables & Cancer survivors & Non-cancer patients \\
& $\mathbf{N}=\mathbf{1 9 0}$ & $\mathbf{N}=\mathbf{4 0 6 9}$ \\
& $\mathbf{N}(\%)$ & $\mathbf{N}(\%)$ \\
\hline Mean (SD) age, years & $62.8(7.5)$ & $58.7(8.1)$ \\
Sex & & \\
Male & $85(44.7)$ & $1.762(43.3)$ \\
Female & $105(55.3)$ & $2.307(56.7)$ \\
Civil status & & \\
Single & $4(2.1)$ & $114(2.9)$ \\
Married/living with a partner & $61(32.1)$ & $1.058(26.8)$ \\
Separated/divorced & $102(53.7)$ & $2.104(53.3)$ \\
Widowed & $16(8.4)$ & $478(12.1)$ \\
Employment status & & $1.616(40.9)$ \\
Not working & $119(72.6)$ & $1.777(45.0)$ \\
Working & $51(26.8)$ & $413(10.5)$ \\
Unemployed & $7(3.7)$ & $14(13.6)$ \\
Long-term sick leave & $13(6.8)$ & \\
Level of education & & \\
Higher/university education & $28(14.7)$ & $583(14.8)$ \\
Secondary education & $54(28.4)$ & $1.523(38.6)$ \\
Primary education & $85(44.7)$ & $1.573(39.8)$ \\
No schooling & $23(12.1)$ & $270(6.8)$ \\
\hline
\end{tabular}

SD standard deviation

The results for lifestyle habits, comorbidities, and social functioning are shown in Table 2. Almost four of every 10 patients in the overall group smoked, and while the rate was somewhat lower among cancer survivors, the difference with non-cancer patients was not significant. Adherence to the Mediterranean diet and physical activity levels were also low overall. Almost $80 \%$ of the members of both groups had low adherence to the Mediterranean diet, and almost $90 \%$ were insufficiently active. Engagement in healthy behaviors was not more common among patients who had survived cancer.

Cancer survivors had significantly worse self-perceived health, more comorbidities, and higher rates of depression, diabetes, and chronic obstructive pulmonary disease (COPD). Both groups had similar perceptions of social support. Multivariate analysis confirmed that cancer survivors had worse self-perceived health than patients who had never had cancer (Table 3).

\section{Discussion}

In this study cancer survivors were on average older than non-cancer patients, perhaps because two-thirds of cancer cases occur in patients aged over 60 years. Older age would also explain why cancer survivors were more likely not to be working and to be on long-term sick leave, although the unemployment rate was lower in this group than in the non-cancer group. Other authors have found that cancer survivors experience difficulties returning to their normal lives, and to work in particular [24]. Islam et al. [25] reported that patients with cancer were 1.4 times more likely to be unemployed than healthy patients due to disease- and treatment-related problems, highlighting the importance of support programs to help them return to work when they are able to [26].

Our study shows similar behaviors among cancer survivors and non-cancer patients in terms of exercise, diet, and smoking, with very high levels of unhealthy behaviors and overweight/obesity in both groups. This observation supports previous reports that modifiable cardiovascular risk factors such as hypertension, obesity, smoking, and physical inactivity are more common in cancer survivors than in the general population [27]. One would expect people who have survived cancer to be more motivated to lead a healthy lifestyle and one would also expert them to receive guidance from their health care providers on how to make suitable changes, particularly in terms of diet and exercise, to prevent recurrent and new cancers, reduce cardiovascular risk factors, and improve quality of life $[12,28]$. Nevertheless, healthy lifestyle choices among cancer survivors and support from health care providers in making these choices would appear to be suboptimal. 
Table 2 Distribution of lifestyle behaviors, comorbidities, and social function

\begin{tabular}{|c|c|c|c|c|}
\hline Variables & $\begin{array}{l}\text { Cancer survivors } \\
\mathrm{N}(\%)\end{array}$ & $\begin{array}{l}\text { Non-cancer patients } \\
\mathrm{N}(\%)\end{array}$ & OR $(95 \% \mathrm{Cl})$ & $P$ \\
\hline \multicolumn{5}{|l|}{ Lifestyle } \\
\hline \multicolumn{5}{|l|}{ Smoking } \\
\hline No & $120(63.2)$ & $2.428(59.7)$ & 1 & \\
\hline Yes & $70(36.8)$ & $1.641(40.3)$ & $0.86(0.63-1.16)$ & 0.33 \\
\hline \multicolumn{5}{|c|}{ Adherence to Mediterranean diet } \\
\hline Good (score $\geq 9$ ) & $35(18.4)$ & $646(16.3)$ & 1 & \\
\hline Low (score 0-8) & $155(81.6)$ & $3.325(83.7)$ & $0.86(0.59-1.25)$ & 0.43 \\
\hline \multicolumn{5}{|l|}{ Physical activity } \\
\hline Insufficiently active & $168(89.4)$ & $3.590(88.8)$ & 1 & \\
\hline Sufficiently active & $20(10.6)$ & $453(11.2)$ & $1.06(0.66-1.70)$ & 0.81 \\
\hline \multicolumn{5}{|l|}{ Health status and social function } \\
\hline \multicolumn{5}{|l|}{ Self-perceived health } \\
\hline Excellent/very good/good & $42(44.2)$ & $1.187(59.1)$ & 1 & \\
\hline Fair/poor & $53(55.8)$ & $823(40.9)$ & $1.82(1.02-2.75)$ & 0.005 \\
\hline \multicolumn{5}{|l|}{ Weight } \\
\hline Normal & $34(17.9)$ & $750(19.0)$ & 1 & \\
\hline Overweight & $62(32.6)$ & $1.442(36.6)$ & $0.94(0.61-1.45)$ & 0.80 \\
\hline Obese & $94(49.5)$ & $1.753(44.4)$ & $1.18(0.79-1.76)$ & 0.41 \\
\hline \multicolumn{5}{|l|}{ No. of health problems } \\
\hline 0 & $67(35.3)$ & $1741(42.8)$ & 1 & \\
\hline 1 & $58(30.5)$ & $1.325(32.6)$ & $1.13(0.79-1.62)$ & 0.48 \\
\hline$\geq 2$ & $65(34.2)$ & $1.003(24.6)$ & $1.68(1.18-2.39)$ & 0.004 \\
\hline \multicolumn{5}{|l|}{ Depression } \\
\hline No & $166(87.4)$ & $3.742(92.0)$ & 1 & \\
\hline Yes & $24(12.6)$ & $327(8.0)$ & $1.65(1.06-2.57)$ & 0.02 \\
\hline \multicolumn{5}{|l|}{ Hypertension } \\
\hline No & $107(56.3)$ & $2.506(61.6)$ & 1 & \\
\hline Yes & $83(43.7)$ & $1.563(38.4)$ & $1.24(0.92-1.66)$ & 0.14 \\
\hline \multicolumn{5}{|c|}{ Chronic obstructive pulmonary disease } \\
\hline No & $175(92.1)$ & $3.915(96.2)$ & 1 & \\
\hline Yes & $15(7.9)$ & $154(3.8)$ & $2.17(1.25-3.78)$ & 0.006 \\
\hline \multicolumn{5}{|c|}{ Diabetes mellitus not affecting target organs } \\
\hline No & $149(78.4)$ & $3.405(83.7)$ & 1 & \\
\hline Yes & 41 (21.6) & $664(16.3)$ & $1.41(0.98-2.01)$ & 0.057 \\
\hline \multicolumn{5}{|l|}{ Self-perceived social support } \\
\hline Standard (score $\geq 32$ ) & $180(95.2)$ & $3.609(95.4)$ & 1 & \\
\hline Low (score <32) & $9(4.8)$ & $296(7.6)$ & $0.61(0.30-1.20)$ & 0.15 \\
\hline
\end{tabular}

Weaver et al. [27] found that just one in three cancer survivors reported having had a health promotion discussion with their health care provider. It has also been found that some survivors are unsure about how to make changes and perceive a lack of support from their health care team [29]. Lifestyle interventions are known to bring about positive lifestyle changes that result in improved health and functioning [30], and these changes should be a primary goal for cancer survivors.
Cancer survivors had worse self-perceived health than non-cancer patients. Depression, COPD, and chronic non-malignant conditions were all more common in this group, supporting previous findings showing a higher prevalence of chronic lifestyle- or treatment-related diseases in cancer survivors compared with members of the general population $[6,30]$. No significant differences were observed for obesity, but this may be because both groups had similar obesity-related risk factors. 
Table 3 Multiple logistic regression analysis

\begin{tabular}{lll}
\hline Variables & Adjusted OR (95\% Cl) & P \\
\hline Age & $1.04(1.001-1.081)$ & 0.014 \\
$\begin{array}{l}\text { Self-perceived health } \\
\text { Excellent/very good/good }\end{array}$ & 1 & \\
$\quad$ Fair/poor & $1.81(1.18-2.78)$ & 0.006 \\
Employment status & & \\
$\quad$ Not working & 1 & 0.07 \\
Working & $0.56(0.29-1.06)$ & 0.09 \\
Unemployment & $0.43(0.15-1.16)$ & 0.32 \\
\hline Long-term sick leave & $1.49(0.67-3.32)$ &
\end{tabular}

OR odds ratio, $\mathrm{Cl}$ confidence interval

\section{Limitations}

- The clinical trial participants had to have at least two modifiable risk behaviors and this means that unhealthy behaviors will have been overrepresented in our sample, preventing us from making population-based estimates of differences between cancer survivors and non-cancer patients.

- Worse health status and higher permanent disability rates among cancer survivors could have been influenced by their older age, although it should be noted that poor self-perceived health remained a significant predictor of cancer survivorship after adjusting for confounders.

- We were unable to gain a broader perspective of health problems that may affect cancer survivors because our sample was small, on some of the more uncommon diseases in the CCI.

\section{Supplementary information}

Supplementary information accompanies this paper at https://doi. org/10.1186/s13104-020-05218-8.

Additional file 1: Figure S1. Flow chart of subjects. Phase II and III study EIRA.

\section{Abbreviations}

RedIAPP: Primary Care Prevention and Health Promotion Network; GPs: General Practitioners; CCI: Charlson Comorbidity Index; COPD: Chronic obstructive pulmonary disease; SD: Standard deviation; OR: Odds ratio.

\section{Acknowledgements}

The authors are grateful to all the researchers within the EIRA trial for their work in coordinating the study and collecting the data. We would also like to thank the primary care physicians and nurses for their efforts during the patient recruitment stage.

\section{Authors' contributions}

BLS and ME conceptualized the sub-study, collected and analyzed the data, and wrote the original draft of the manuscript. EZdO, JL, B BR, TL, MCC conceptualized phases II and III of the EIRA trial, coordinated the data collection, and reviewed and edited the draft manuscript. All authors read and approved the final manuscript.

\section{Funding}

This study was funded by a research grant from the Instituto de Salud Carlos III Institute of Health at the Spanish Ministry of Economy and Competitiveness. In Catalonia: PI15/00114, Pl15/00565, PI15/0519; Castilla y León: PI15/00762; Aragón: PI15/00896; Mallorca: PI15/01412; Andalusia: PI15/01151; Euskadi: PI15/01072; Galicia: PI15/01133.This funding was applicable only to data collection and fees for conference attendance and publication. The project also received partial funds from the RedIAPP Preventive Activities and Health Promotion Network (RD12/0005; RD16/0007) for data collection by the coordinating researcher, from the Spanish Cancer League, Balearic Association (2012) for the translation of the manuscript, and from the Catalan Department of Health (SLT002/16/00/00112) for a data manager contract.

\section{Availability of data and materials}

The datasets used and analyzed during the current study are available from the corresponding author on reasonable request. effects that leading a healthy lifestyle can have on quality of life and prognosis. 


\section{Ethics approval and consent to participate}

The study was approved by the Research Ethics Committee of Institut Universitari d'Investigació en Atenció Primària Jordi Gol (IDIAP Jordi Gol) (approval number P16/025). The primary health care professionals explained the study to the participants and obtained signed consent from those who agreed to participate. The study complies with all applicable personal data protection laws. All data collection forms were assigned a coded ID number only to ensure participant confidentiality.

\section{Consent to publish}

Informed consent was obtained from the study participants for the publication of data.

\section{Competing interests}

The authors declare that they have no competing interests.

\section{Author details}

${ }^{1}$ Canarian Foundation in Health Care Research (FUNCANIS), Camino Candelaria, 44. CS San Isidro-El Chorrillo, 38109 El Rosario, Santa Cruz de Tenerife, Spain. ${ }^{2}$ Preventive Activities and Health Promotion Research Network (REDIAPP), Barcelona, Spain. ${ }^{3}$ Health Services Research in Chronic Diseases Network (REDISSEC), Barakaldo, Spain. ${ }^{4}$ University Institute for Research in Primary Care Jordi Gol I Gurina (IDIAPJGol), Gran Via de Les Corts Catalanes, 587, 08007 Barcelona, Spain. ${ }^{5}$ Barcelona Health District, Catalonial Health Institute, Barcelona, Spain. ${ }^{6}$ Faculty of Nursing, University of Girona, Girona, Spain. ${ }^{7}$ Autonomous University of Barcelona, Bellaterra, Spain. ${ }^{8}$ Unit of Research Majorca Department of Primary Care, Balearic Health Service, Escola Graduada 3, 07002 Palma, Majorca, Spain. ${ }^{9}$ Balearic Islands Health Research Institute (IdISBa), University Hospital of Son Espases, Carretera de Valldemossa, 79, 07120 Palma, Majorca, Spain.

Received: 21 June 2020 Accepted: 30 July 2020

Published online: 08 August 2020

\section{References}

1. Allemani C, Matsuda T, Di Carlo V, Harewood R, Matz M, Nikšić M, Bonaventure A, Valkov M, Johnson CJ, Estève J, Ogunbiyi OJ, Silva GAE, Chen WQ, Eser S, Engholm G, Stiller CA, Monnereau A, Woods RR, Visser O, Lim GH, Aitken J, Weir HK, Coleman MP, CONCORD Working Group. Global surveillance of trends in cancer survival 2000-14 CONCORD-3: analysis of individual records for 37513025 patients diagnosed with one of 18 cancers from 322 population-based registries in 71 countries. Lancet. 2018. https://doi.org/10.1016/S0140-6736(17)33326-3.

2. Galceran J, Ameijide A, Carulla M, Mateos A, Ramón Quirós J, Alemán A, et al. Estimaciones de la incidencia y la supervivencia del cáncer en España y su situación en Europa. 2014. https://redecan.org/redecan.org/ es/444_Estimaciones_Incidencia_y_Supervi_Cancer_en_Espa_na_2014 DEF_DEF3a26.pdf?file=257\&area=196. Accessed 20 May 2019.

3. Lopez-Abente G, Nuñez O, Perez-Gomez B, Aragones N, Pollan M. La Situación del Cáncer en España: Informe. 2015. https://www.isciii.es/QueHa cemos/Servicios/VigilanciaSaludPublicaRENAVE/EnfermedadesCronicas/ Documents/informes/cancer2015.pdf. Accesed 20 May 2019.

4. Grunfeld E, Earle CC. The interface between primary and oncology specialty care: treatment through survivorship. JNCI Monogr. 2010. https ://doi.org/10.1093/jncimonographs/lgq002.

5. Khan NF, Mant D, Carpenter L, Forman D, Rose PW. Long-term health outcomes in a British cohort of breast, colorectal and prostate cancer survivors: a database study. Br J Cancer. 2011. https://doi.org/10.1038/ bjc.2011.420.

6. Demark-Wahnefried W, Schmitz KH, Alfano CM, Bail JR, Goodwin PJ, Thomson CA, et al. Weight management and physical activity throughout the cancer care continuum. CA Cancer J Clin. 2018. https://doi. org/10.3322/caac.21441.

7. Ballard-Barbash R, Friedenreich CM, Courneya KS, Siddiqi SM, McTiernan A, Alfano CM. Physical activity, biomarkers, and disease outcomes in cancer survivors: a systematic review. J Natl Cancer Inst. 2012. https://doi. org/10.1093/jnci/djs207.
8. Klein WM, Bloch M, Hesse BW, McDonald PG, Nebeling L, O'Connell ME, et al. Behavioral research in cancer prevention and control. Am J Prev Med. 2014. https://doi.org/10.1016/j.amepre.2013.10.004.

9. Garcia DO, Thomson CA. Physical activity and cancer survivorship. Nutr Clin Pract. 2014. https://doi.org/10.1177/0884533614551969.

10. Lemanne D, Cassileth B, Gubili J. The role of physical activity in cancer prevention, treatment, recovery, and survivorship. Oncology. 2013;27:580-5

11. Johnston-Early A, Cohen MH, Minna JD, Paxton LM, Fossieck BE, Ihde DC, et al. Smoking abstinence and small cell lung cancer survival an association. JAMA. 1980;24419:2175-9.

12. Davies NJ, Batehup L, Thomas R. The role of diet and physical activity in breast, colorectal, and prostate cancer survivorship: a review of the literature. Br J Cancer. 2011. https://doi.org/10.1038/bjc.2011.

13. Pekmezi DW, Demark-Wahnefried W. Updated evidence in support of diet and exercise interventions in cancer survivors. Acta Oncol. 2011. https://doi.org/10.3109/0284186X.2010.529822.

14. Tiedtke C, de Rijk A, Dierckx de Casterlé B, Christiaens MR, Donceel P. Experiences and concerns about "returning to work" for women breast cancer survivors: a literature review. Psychooncology. 2009. https://doi. org/10.1186/1471-2458-12-538.

15. Ferro T, Aliste L, Valverde M, Fernández MP, Ballano C, Borràs JM. Health status and health resource use among long-term survivors of breast, colorectal and prostate cancer. Gac Sanit. 2014. https://doi.org/10.1016/j. gaceta.2013.09.002

16. Craig P, Dieppe P, Macintyre S, Michie S, Nazareth I, Petticrew M. Developing and evaluating complex interventions: the new Medical Research Council guidance Revisiting the 2000 MRC framework. BMJ. 2008. https:// doi.org/10.1136/bmj.a1655.

17. Zabaleta-Del-Olmo E, Pombo H, Pons-Vigués M, et al. Complex multiple risk intervention to promote healthy behaviours in people between 45 to 75 years attended in primary health care (EIRA study): study protocol for a hybrid trial. BMC Public Health. 2018. https://doi.org/10.1186/s1288 9-018-5805-y.

18. Broadhead WE, Gehlbach SH, de Gruy FV, Kaplan BH. The Duke-UNC Functional Social Support Questionnaire. Measurement of social support in family medicine patients. Med Care. 1988;267:709-23.

19. Bellón Saameño JA, Delgado Sánchez A, Luna del Castillo JD, Lardelli CP. Validity and reliability of the Duke-UNC-11 questionnaire of functional social support. Aten Primaria. 1996:18:153-63.

20. Charlson ME, Pompei P, Ales KL, Mackenzie CR. A new method of classifying prognostic comorbidity in longitudinal studies: development and validation. J Chronic Dis. 1987;405:373-83.

21. Estruch R, Ros E, Salas-Salvadó J, Covas M-I, Corella D, Arós F, et al. Primary prevention of cardiovascular disease with a Mediterranean diet. N Engl J Med. 2013. https://doi.org/10.1056/NEJMoa1800389.

22. Puig Ribera A, Peña Chimenis Ò, Romaguera Bosch M, Duran Bellido E, Heras Tebar A, Solà Gonfaus M, et al. Cómo identificar la inactividad física en atención primaria: validación de las versiones catalana y española de 2 cuestionarios breves. Aten Primaria. 2012. https://doi.org/10.1016/j.aprim .2012.01.005.

23. Marshall AL, Smith BJ, Bauman AE, Kaur S. Reliability and validity of a brief physical activity assessment for use by family doctors. Br J Sports Med. 2005;395:294-7.

24. Molina R, Feliu J. The return to work of cancer survivors: the experience in Spain. Work. 2013. https://doi.org/10.3233/WOR-131677.

25. Islam T, Dahlui M, Majid H, Nahar A, Mohd Taib N, Su T, et al. Factors associated with return to work of breast cancer survivors: a systematic review. BMC Public Health. 2014. https://doi.org/10.1186/1471-2458-14-S3-S8.

26. de Boer AG, Taskila TK, Tamminga SJ, Feuerstein M, Frings-Dresen MH, Verbeek $\mathrm{JH}$. Interventions to enhance return-to-work for cancer patients. Cochrane Database Syst Rev. 2015. https://doi.org/10.1002/14651858. CD007569.

27. Weaver KE, Foraker RE, Alfano CM, Rowland JH, Arora NK, Bellizzi KM, et al. Cardiovascular risk factors among long-term survivors of breast, prostate, colorectal, and gynecologic cancers: a gap in survivorship care? J Cancer Surviv. 2013. https://doi.org/10.1007/s11764-013-0267-9.

28. Schwedhelm C, Boeing H, Hoffmann G, Aleksandrova K, Schwingshackl L. Effect of diet on mortality and cancer recurrence among cancer survivors: a systematic review and meta-analysis of cohort studies. Nutr Rev. 2016:7412:737-48. 
29. Corbett T, Cheetham T, Müller AM, Slodkowska-Barabasz J, Wilde L, Krusche A, et al. Exploring cancer survivors' views of health behaviour change: "Where do you start, where do you stop with everything?". Psychooncology. 2018;27(7):1816-24. https://doi.org/10.1002/pon.4732

30. Morey MC, Snyder DC, Sloane R, Cohen HJ, Peterson B, Hartman TJ, et al. Effects of home-based diet and exercise on functional outcomes among older, overweight long-term cancer survivors. JAMA. 2009. https://doi. org/10.1001/jama.2009.643.

31. Caravati-Jouvenceaux A, Launoy G, Klein D, Henry-Amar M, Abeilard E, Danzon A, et al. Health-related quality of life among long-term survivors of colorectal cancer: a population-based study. Oncologist. 2011. https:// doi.org/10.1634/theoncologist.2011-0036.

32. Arndt V, Merx H, Stegmaier C, Ziegler H, Brenner H. Quality of life in patients with colorectal cancer 1 year after diagnosis compared with the general population: a population-based study. J Clin Oncol. 2004;2223:4829-36.
33. Schneider EC, Malin JL, Kahn KL, Ko CY, Adams J, Epstein AM. Surviving colorectal cancer. Cancer. 2007;1109:2075-82.

34. Ramsey SD, Berry K, Moinpour C, Giedzinska A, Andersen MR. Quality of life in long term survivors of colorectal cancer. Am J Gastroenterol. 2002;975:1228-344.

35. Schroevers M, Ranchor AV, Sanderman R. Adjustment to cancer in the 8 years following diagnosis: A longitudinal study comparing cancer survivors with healthy individuals. Soc Sci Med. 2006;633:598-610.

\section{Publisher's Note}

Springer Nature remains neutral with regard to jurisdictional claims in published maps and institutional affiliations.
Ready to submit your research? Choose BMC and benefit from:

- fast, convenient online submission

- thorough peer review by experienced researchers in your field

- rapid publication on acceptance

- support for research data, including large and complex data types

- gold Open Access which fosters wider collaboration and increased citations

- maximum visibility for your research: over 100M website views per year

At BMC, research is always in progress.

Learn more biomedcentral.com/submissions 